\title{
Incidence and differences in urban-rural seasonal variation of Type 1 (insulin-dependent) diabetes in Wisconsin
}

\author{
C.Allen, M.Palta and D.J.D.'Alessio \\ Departments of Preventive Medicine and Medicine, University of Wisconsin Center for Health Sciences, Madison, Wisconsin, USA
}

\begin{abstract}
Summary. In a hospital-based records study of Type 1 (insulin-dependent) diabetes mellitus among persons aged 0 to 29 years in two Wisconsin, USA counties (1970-79), the age-adjusted yearly incidence rate for white males $(16.4 / 100,000)$ was significantly higher than for white females $(11.6 / 100,000)$ $(p=0.006)$. Overall age-adjusted rates are similar to rates previously reported for the United States and the northern European countries of Denmark and Norway. Seasonal variation in diagnosis was found for total cases and males aged 10 to 19 years. A striking difference also was found in seasonal diagnosis between urban and rural cases. A diagnosis peak in the
\end{abstract}

third and fourth quarter among rural cases contrasted with even quarterly distribution among urban cases. In addition, $52 \%$ of rural male cases aged 10 to 19 years were diagnosed during the fourth quarter while no seasonal pattern occurred among urban males the same ages. These findings identify subgroups for focus of future etiologic investigations.

Key words: Diabetes mellitus, juvenile, etiology, insulin-dependent diabetes, occurrence, seasonal variation, Type 1 diabetes.
Descriptive epidemiologic studies of Type 1 (insulin-dependent) diabetes in Europe have provided divergent estimates of incidence rates, secular trends and seasonal variation of onset [1-5]. Although some of the variability may be attributable to differences in methodology, comparisons of Type 1 diabetes incidence among countries [1, 2, 4-7] suggest that environmental exposures and/or ethnicity are important to etiology. Another line of evidence suggesting a role for environmental exposure in the development of overt diabetes is the seasonal onset described in population-based studies $[1-3,8]$.

Relatively little incidence data have been published from North America. Previous hospital-based studies $[6,7]$ which were similar in methodology to European studies have provided some basis for comparison. We undertook a hospital-based incidence study of Type 1 diabetes mellitus in two area of Wisconsin, USA, to examine incidence and seasonal onset in this region. Our study additionally addresses Type 1 diabetes in rural USA populations.

\section{Subjects and methods}

\section{Subjects}

Denominator population. A hospital-based records study was carried out retrospectively for the period 1970-1979 in two Wisconsin (upper Midwest) counties, Dane and La Crosse. Dane County, in south cen- tral Wisconsin, covers an area of 1,233 square miles $\left(3,194 \mathrm{~km}^{2}\right)$ and contains the state capital, Madison; La Crosse County is in western Wisconsin and covers an area of 474 square miles $\left(1,228 \mathrm{~km}^{2}\right)$. Both areas contain three types of municipalities (political/geographical boundaries) - cities, villages and townships - with population densities ranging from 10 to 1,855 persons per square mile $\left(4-716 / \mathrm{km}^{2}\right)$ in Dane County and from 9 to 1,590 persons per square mile $\left(4-614 / \mathrm{km}^{2}\right)$ in La Crosse County. Villages and townships are mostly agricultural, but also serve as housing areas for those working in cities. Populations in both counties are primarily of northern European ancestry and are $97 \%$ Caucasian [9].

Base population estimates for each county and municipalities within each county were interpolated from 1970 and 1980 U.S. Census reports $[10,11]$. Two adjustments have been made to census figures to improve accuracy of denominator population estimates. First, since both counties include college populations represented in the census and diabetes diagnosis is possible in this group while school is not in session, data were obtained from each college to identify the proportion of students who were not permanent residents of either county. These non-resident college populations were subtracted from appropriate sex and 5-year age groups in the census figures, and nonresident students were not included as cases. Secondly, because cases were drawn from hospitals only, the proportion of residents in each study county utilizing a hospital outside the county (less than five percent in each region) was identified from the 1976-1977 Wisconsin Hospital Discharge Survey [12] and omitted from base population estimates. Therefore, the population base represents white permanent residents within each study county who utilize hospital facilities contained within its boundaries.

Urban populations were distinguished from rural on the basis of both the total population count and population density of municipalities. The two municipalities with the largest population counts, the city of Madison and the city of La Crosse, were also the only major 
population centres. Their mean populations for the study period were 171,153 and 49,220 respectively [10, 11]. No other municipality exceeded a population of 10,000 persons. Any municipality adjacent to the cities of Madison or La Crosse with a similar population density (i. e. greater than or equal to 1,000 persons/square mile, or $386 / \mathrm{km}^{2}$ ) was included with these two cities to comprise the urban boundaries. All other municipalities were considered rural.

Numerator (cases). Record searches using hospital disease indices were carried out at all five community hospitals in Dane County (four in Madison) and both community hospitals in the city of La Crosse. All white patients aged 0 to 29 years, admitted from 1970-1979 and discharged with a primary diagnosis [13] of newly diagnosed diabetes mellitus requiring insulin therapy, were identified as new cases. Date of diagnosis was taken as the first day of exogenous insulin administration. Non-permanent resident college students identified from the admission data sheet and social history were eliminated. Cases residing outside county boundaries were excluded from the incidence estimates of this study.

\section{Methods}

Health care patterns and case ascertainment. The cities of Madison and $\mathrm{La}$ Crosse contain major medical facilities recognized as centres of health care for their areas and surrounding areas in the state. Health care is centralized within each county in that all general hospitals except one 70-bed hospital are located in Madison and the city of La Crosse, and more than half of the smaller clinics outside either city are affiliated with Madison or La Crosse clinics. The closest major medical facility outside either county is more than 60 miles $(97 \mathrm{~km})$ from the study boundary.

The method of case ascertainment was evaluated by a mailed questionnaire to all paediatricians, general and family practitioners in each county, as well as each patient's attending physician. The questionnaire response rate was 84 percent: $81 \%$ among physicians in urban areas and 96\% among physicians in rural areas. Physicians were

Table 1. Age-specific and age-adjusted incidence rates of 'Type 1 (insulin-dependent) diabetes cases mellitus cases under age 30 in Dane and La Crosse counties, Wisconsin, USA, 1970-1979

\begin{tabular}{llllllll}
\hline $\begin{array}{l}\text { Age } \\
\text { group } \\
\text { (years) }\end{array}$ & \multicolumn{2}{l}{ Dane county } & & \multicolumn{3}{l}{ La Crosse county } \\
\cline { 2 - 3 } \cline { 6 - 7 } & $\begin{array}{l}\text { Number } \\
\text { of } \\
\text { cases }\end{array}$ & $\begin{array}{l}\text { Popula- } \\
\text { tion }\end{array}$ & $\begin{array}{l}\text { Incidence } \\
\text { rate/ } \\
100,000\end{array}$ & $\begin{array}{l}\text { Number } \\
\text { of } \\
\text { cases }\end{array}$ & $\begin{array}{l}\text { Popula- } \\
\text { tion }\end{array}$ & $\begin{array}{l}\text { Incidence } \\
\text { rate/ } \\
100,000\end{array}$ \\
\hline $0-14$ & 130 & 69,089 & 18.8 & 36 & 20,064 & 17.9 \\
$15-29$ & 79 & 74,397 & 10.6 & & 23 & 20,685 & 11.1 \\
Age-adjusted rate & & 14.0 & & & 14.1 \\
\hline
\end{tabular}

${ }^{a}$ Standard error Dane county $=0.98 / 100,000$. Standard error La Crosse county $=1.85 / 100,000$ asked to characterize their practice as "always, usually, sometimes or never" hospitalizing patients at the time of Type 1 diabetes diagnosis. Among physicians treating Type 1 diabetic patients during 1970-1979, $86 \%$ (all specialties) reported that they "always" hospitalized patients at onset. Only one paediatrician indicated "sometimes" hospitalizing at onset. Physicians also were asked to specify if they had treated any new patients during 1970-1979 on an outpatient basis at disease onset: $13.6 \%$ of physicians at clinics in urban areas and $10.5 \%$ of physicians in rural areas reported they had. No physician reported referral of cases to hospitals outside either county. Ascertainment by hospital records is estimated at greater than $90 \%$ for ages 0 to 19 and about $75 \%$ for ages 20 to 29 based on calculating the frequency of outpatient treatment at diabetes onset (mailed physician questionnaire) by physician specialty. All assumptions made to estimate ascertainment were conservative; since external validation has supported this method of hospital case finding previously $[1,7]$ we conclude that the rates we report accurately reflect the occurrence of Type 1 diabetes in the regions studied.

\section{Statistical analysis}

Direct age and sex adjustment was done using as the standard the average 10-year county and municipality population estimates based on the 1970 and 1980 U.S. Census reports [11, 12, 14, 15].

Statistical analysis for secular trends was done by linear regression [16]. Statistical analyses of monthly seasonal diagnoses were done using St. Leger's test [17].

\section{Results}

\section{Incidence}

For the period 1970-1979, 307 newly diagnosed patients with Type 1 diabetes mellitus aged 0 to 29 years, of whom 268 resided within county boundaries, were identified. Of these 268 cases, 209 (78\%) resided in Dane County and $59(22 \%)$ in La Crosse County (Table 1). Incidence rates between urban populations of each county and rural populations of each county were comparable, and age-adjusted incidence rates for the two counties were found to be identical at $14 / 100,000$. Therefore, the data from both areas were combined in the following analyses.

Males comprised $57.5 \%$ of the cases identified (Table 2) and their age-specific incidence rates exceeded those among females in every 5-year age group.

Table 2. Age-specific and age-adjusted incidence rates of Type 1 diabetes mellitus cases under age 30 in Wisconsin, 1970-1979, by sex

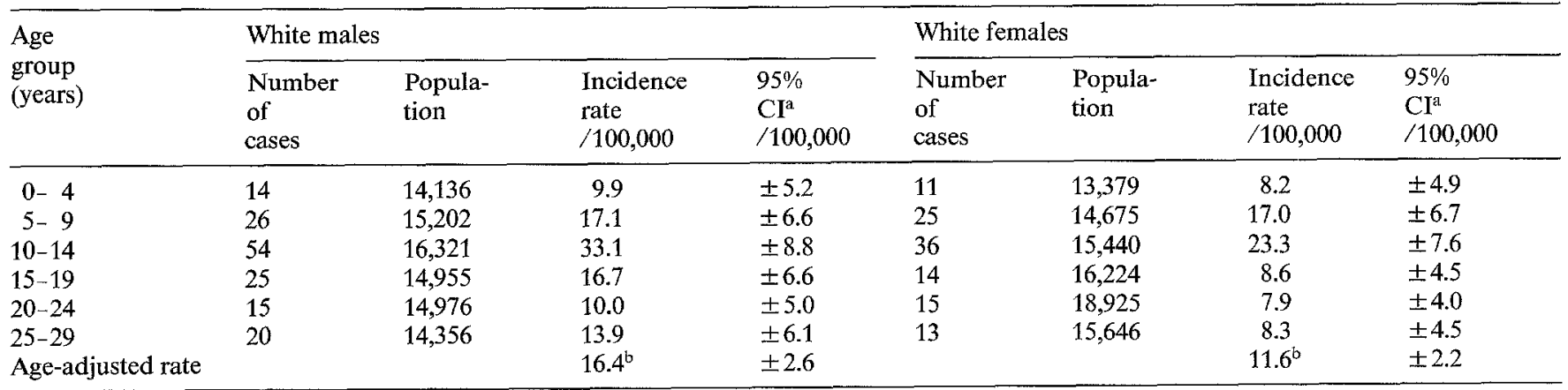

${ }^{\mathrm{a}}$ Confidence interval; ${ }^{\mathrm{b}}$ significant difference; $p=0.006$ 
The age-adjusted male rate of $16.4 / 100,000$ was significantly different $(p=0.006$ ) from the $11.6 / 100,000$ for females [18].

Peak incidence of Type 1 diabetes occurred among males age 10 to 14 years, and the next highest rate was among females of the same age range. A steadily increasing gradient with age to peak incidence was seen for both sexes, with a sharper decline among females following the peak. Mean age at diagnosis was 14.0 years for males and 13.8 for females.

No statistically significant temporal differences - either a linear trend or deviation from mean distribution - for the 10-year period were observed among males, females or total cases. Yearly age-adjusted incidence rates ranged from $6.6 / 100,000$ among females in 1972 to $21.0 / 100,000$ among males in 1976 (Table 3 ).

Age-specific incidence rates among urban males were consistently higher than among rural males (Table 4). For both the 0 to 14 - and 15 to 29 -year age groups studied, urban males had approximately 4 cases per 100,000 more than rural males $(p>0.10)$ [18].

Table 3. Age-adjusted incidence of Type 1 diabetes mellitus cases diagnosed under age 30 in Wisconsin, by year and by sex

\begin{tabular}{|c|c|c|c|c|c|}
\hline \multirow[t]{2}{*}{ Year } & \multicolumn{2}{|c|}{ White males } & \multicolumn{3}{|c|}{ White females } \\
\hline & $\begin{array}{l}\text { Number } \\
\text { of } \\
\text { cases }\end{array}$ & $\begin{array}{l}\text { Age-adjusted } \\
\text { incidence } \\
\text { rate } \\
/ 100,000\end{array}$ & $\begin{array}{l}\text { Number } \\
\text { of } \\
\text { cases }\end{array}$ & $\begin{array}{l}\text { Age-adjusted } \\
\text { incidence } \\
\text { rate } \\
/ 100,000\end{array}$ & $\begin{array}{l}\text { Total } \\
\text { number } \\
\text { of } \\
\text { cases }\end{array}$ \\
\hline 1970 & 17 & 18.9 & 12 & 11.7 & 29 \\
\hline 1971 & 14 & 15.2 & 9 & 7.8 & 23 \\
\hline 1972 & 16 & 15.5 & 7 & 6.6 & 23 \\
\hline 1973 & 17 & 20.4 & 17 & 17.8 & 34 \\
\hline 1974 & 14 & 15.6 & 10 & 10.3 & 24 \\
\hline 1975 & 19 & 19.9 & 15 & 14.3 & 34 \\
\hline 1976 & 20 & 21.0 & 11 & 9.7 & 31 \\
\hline 1977 & 13 & 13.7 & 7 & 7.1 & 20 \\
\hline 1978 & 12 & 12.9 & 17 & 17.5 & 29 \\
\hline 1979 & 12 & 13.0 & 9 & 10.1 & 21 \\
\hline
\end{tabular}

Among urban and rural females, rates showed no consistent differences and did not vary as widely as between urban and rural males.

\section{Seasonal variation}

Seasonal trends for the month of diabetes diagnosis were observed for the total 307 cases (268 county residents plus 39 non-county cases) identified. Aggregation of diagnoses occurred in the fourth quarter, in which 95 cases $(31 \%)$ were observed. A smaller peak was observed in early spring. Among subgroups studied (by 5and 10-year sex-specific age groups), aggregation of diagnoses occurred only in males aged 10 to 19 years, with $38 \%$ of cases diagnosed in the fourth quarter of the year. A smaller peak similar to that for the total cases occurred in March. Seasonal trends were significant for total cases and males aged 10 to 19 years $(p=0.05)$. Analyses of all cases except males aged 10 to 19 indicates that this subgroup explains the seasonal variation found for the group as a whole. Monthly diagnoses among females were highly variable for each age group studied, and no aggregation of diagnoses was observed. Females aged 10 to 19 years showed an even quarterly distribution.

A striking difference in seasonal variation by month of diagnosis was observed between urban and rural cases residing in the two study counties (Fig.1). Constant incidence among urban cases contrasted with a summer increase and late fall peak among rural cases. Urban residents had an almost uniform quarterly distribution of diagnoses $(26,25,22,27 \%$, respectively) while $38 \%$ of rural cases occurred in the fourth quarter. Quarterly distributions between these two groups were significantly different $\left(\chi^{2}, 0.025<\mathrm{p}<0.05\right)$. There were no significant differences in urban-rural case presentation with regard to admission blood glucose, venous bicarbonate or carbon dixide ( $t$ test) or ketonaemia [18].

The fourth quarter peak observed among rural males aged 10 to 19 years was even more pronounced

Table 4. Age-specific and age-adjusted incidence of Type 1 diabetes cases in urban versus rural Dane and La Crosse counties, Wisconsin, 1970-1979

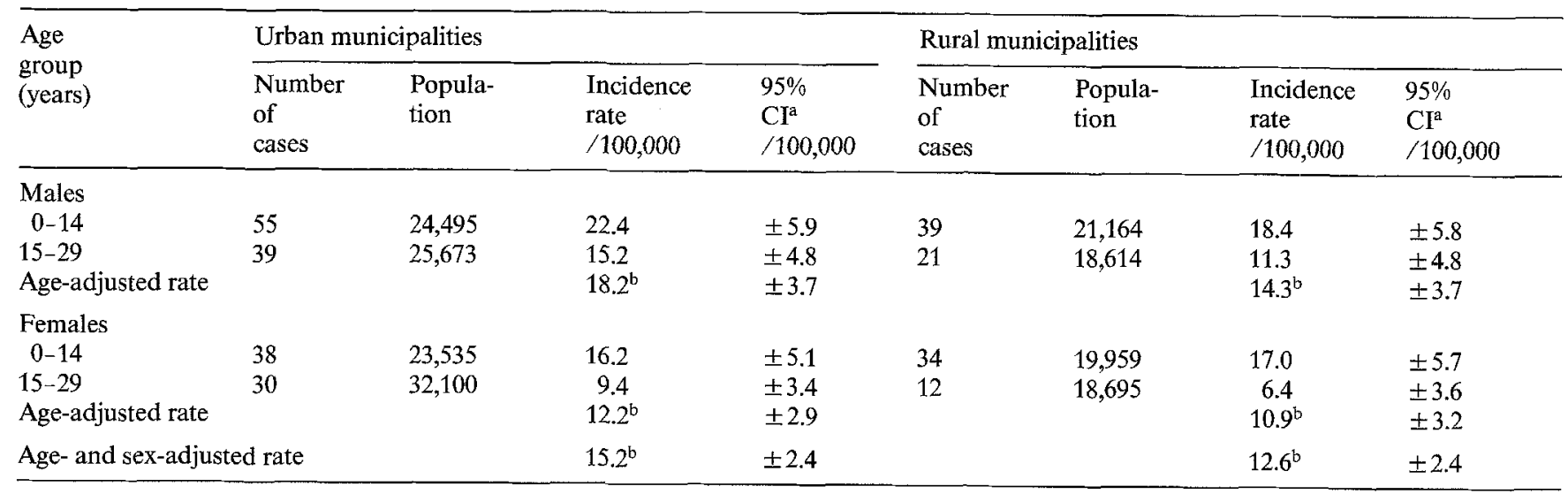

${ }^{\mathrm{a}}$ Confidence interval; ${ }^{\mathrm{b}}$ no significant difference; $p>0.05$ 


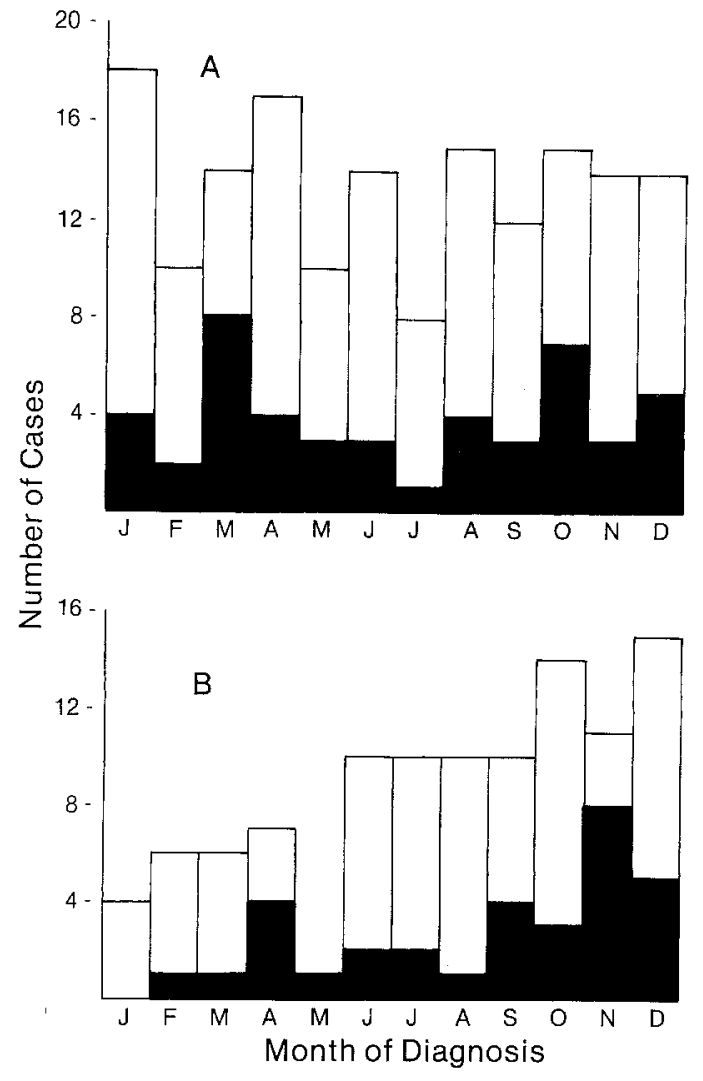

Fig. 1. A Urban versus $\mathbf{B}$ rural monthly diagnosis of Type 1 diabetes mellitus cases in two Wisconsin counties, 1970-1979. Males aged 10 to 19 years. $\square$ All cases aged 0 to 29 years

Table 5. Comparison of age-adjusted incidence rates of Type 1 diabetes mellitus in Allegheny county, PA, USA [7], Denmark [1] and Wisconsin

\begin{tabular}{llll}
\hline $\begin{array}{l}\text { Incidence } \\
\text { rate } 100,000\end{array}$ & $\begin{array}{l}\text { Allegheny } \\
\text { county, } \\
\text { Pennsylvania }\end{array}$ & Denmark Wisconsin \\
\hline $\begin{array}{l}\text { Published } \\
\text { age-adjusted rate }\end{array}$ & 16.02 & 14.8 & 16.4 \\
Males & 14.79 & 11.7 & 11.6 \\
Females & & & \\
Age-adjusted to & & & \\
Wisconsin standard & 15.6 & 15.4 & 19.4 \\
population & 14.0 & 12.3 & 14.0 \\
Males 0-19 & - & 15.0 & 16.4 \\
Females 0-19 & - & 11.7 & 11.6 \\
Males 0-29 & & & \\
Females 0-29 & & & \\
\hline
\end{tabular}

(Fig. 1). Fifty-two percent of cases occurred in the fourth quarter for this subgroup. Although this seasonal pattern was not observed for urban males age 10 to 19 years, quarterly distributions between these two subgroups were not significantly different $\left(\chi^{2}, 0.05<p<\right.$ $0.10)$.

Seasonal variation by month of diagnosis was significant among the total rural cases $(p<0.005)$, but not among rural males aged 10 to 19 years $(0.05<\mathrm{p}<0.10)$.

\section{Discussion}

Our study addresses two areas of inconclusive Type 1 diabetes epidemiology, incidence and seasonal onset. A number of studies have been published recently that have improved on methodological problems which compromised earlier incidence estimates $[1,2,4,6,7]$. Even among these, differences in methods and age groups studied make the variation in incidence observed difficult to evaluate. In case definition, ascertainment methods, and age groups studied our data most closely parallel those reported from Denmark [1] and show good agreement in age-adjusted rates. Studies from Allegheny County [7] and Norway [2] found slightly higher age-adjusted rates that probably reflect the younger populations studied ( $0-19$ years in Allegheny County and $0-14$ years in Norway). Age-adjusted rates for Denmark and Allegheny County recalculated using the standard population from our study (Table 5) show little difference in Type 1 diabetes incidence rates. Neither Allegheny County or the two Wisconsin counties studied have large Scandinavian populations, but these counties are predominantly northern European in ancestry with at least half of Germanic heritage [9]. In contrast, the incidence rate observed in Montreal, a city of French heritage $(8.8 / 100,000)$ [4], differs markedly.

Inter-country differences in Type 1 diabetes rates may be partially explained by gene pools [19]. The general finding of an increase in diabetes incidence from southern to northern Europe can be applied to Allegheny County, Wisconsin and Montreal. Incidence rates compare well with the predominant ancestries of these North American populations: Allegheny County and Wisconsin with Northern Europe, and Montreal with France [19]. A less compelling explanation for a gradient in incidence rates is variability in climate. Wisconsin has both hotter summers and colder winters than Northern Europe, but the incidence rates compare closely.

Regional differences have been reported in Norway, Sweden and Finland [2-4]. Our study shows higher, but not significantly different, incidence rates for urban cases. Although the above studies did not characterize cases as urban or rural, it appears that increased incidence rates were found in the more densely populated areas. This intra-country variability in rates is not likely explained by local differences in gene pools and suggests a role for environmental factors. Our finding of seasonal variation in diabetes diagnoses among rural but not urban cases adds a dimension that has not been reported previously. There were no differences in urban-rural case presentation based on selected laboratory tests to suggest that rural cases delayed their diagnoses to a particular time of year.

One explanation of seasonal diagnoses is an association with infectious agents that vary seasonally [20, 21]. However, this necessitates a subsequent explanation of why it is unique to rural and not urban cases. It 
may be that multiple precipitating or initiating environmental exposures affect urban cases making seasonal variation inapparent.

Finally, our finding of a higher incidence of diabetes in males has been reported by others [1-3, 5]. Our malefemale incidence ratios for the six age groups respectively $(1.21,1.01,1.42,1.94,1.27,1.68)$ compare closely to those observed in Denmark (1.04, 1.02, 1.13, 1.81, $1.16,1.68)[22]$. Increased rates of illness among males is a common finding in infectious disease. On the basis of virus antibody studies and seasonal onset of disease, an association of infectious agents with the onset of Type 1 diabetes has been suggested. However, a role for infectious agents would need to be identified along with the already firmly established importance of genetic predisposition [23-25]. Our study suggests that future epidemiologic investigations of Type 1 diabetes etiology should incorporate specific characterizations of urban and rural populations into a genetic-environmental exposure framework.

Acknowledgements. This work was supported in part by the Wisconsin Division of Health, Bureau of Community Health and Prevention, from Title V Public Health Act, Maternal and Child Health funds.

\section{References}

1. Christau B, Kromann H, Christy M, Andersen OO, Nerup J (1979) Incidence of insulin-dependent diabetes mellitus $(0-29$ years at onset) in Denmark. Acta Med Scand 624 (Suppl); 54-60

2. Joner $G$, Sovik O (1981) Incidence, age at onset and seasonal variation of diabetes mellitus in Nowegian children, 1973-1977. Acta Paediatr Scand 70: 329-335

3. Sterky G, Holmgren G, Gustavson KH, Larsson $Y$, Lundmark KM, Nilsson KO, Samuelson G, Thalme B, Wall S (1978) The incidence of diabetes mellitus in Swedish children 1970-1975. Acta Paediatr Scand 67: 139-143

4. Reunanen A, Akerblom HK, Kaar M-L (1982) Prevalence and tenyear (1970-1979) incidence of insulin-dependent diabetes mellitus in children and adolescents in Finland. Acta Pediatr Scand 71: 893-899

5. Patterson, CC, Thorogood, M, Smith PG, Heasman MA, Clarke JA, Mann JI (1983) Epidemiology of Type 1 (insulin-dependent) diabetes in Scotland 1968-1976: evidence of an increasing incidence. Diabetologia 24: 238-243

6. West R, Belmonte MM, Colle E, Crepeau MP, Wilkins J, and Poirier R (1979) Epidemiologic survey of juvenile-onset diabetes in Montreal. Diabetes 28: 690-693

7. LaPorte RE, Fishbein HA, Drash AL, Kuller LH, Schneider BB, Orchard TJ, Wagener DK (1981) The Pittsburgh insulin-dependent diabetes mellitus (IDDM) registry: The incidence of insulindependent diabetes mellitus in Allegheny County, Pennsylvania (1965-1976). Diabetes 30: 279-284
8. Fishbein HA, LaPorte RE, Orchard TJ, Drash AL, Kuller LH, Wagener DK (1982) The Pittsburgh insulin-dependent diabetes mellitus registry: seasonal incidence. Diabetologia 23: 83-85

9. United States Department of Commerce, Bureau of the Census (1980) General Social and Economic Characteristics, Table 60. US Govt Printing Office, Washington, DC

10. United States Department of Commerce, Bureau of the Census (1970) General Population Characteristics, BC(1)-B51 GPC, Wisconsin. US Govt Printing Office, Washington, DC

11. United States Department of Commerce Bureau of the Census (1980) General Population Characteristics, BC(1)-B51 GPC, Wisconsin. US Govt Printing Office, Washington, DC

12. Wisconsin Department of Health and Social Services (1977) Wisconsin Hospital Morbidity - patient origin and destination report 1976-1977. Bureau of Health Statistics, Madison, Wisconsin

13. World Health Organization (1980) ICD-9-CM International Classification of Diseases 1: 159-161

14. United States Department of Commerce, Bureau of the Census (1970) General Population Characteristics, Summary Tape (Table 202), Wisconsin

15. United States Department of Commerce Bureau of the Census (1980) General Population Characteristics, Summary Tape (File 1A), Wisconsin

16. Baker RJ, Nelder JA (1978) The GLIM (Generalized Linear Interactive Modelling) System. Numerical Algorithms Group, Oxford

17. St. Leger AS (1976) Comparison of two tests for seasonality in epidemiological data. Appl Statist 25:280-286

18. Anderson TW, Sclove SL (1978) An introduction to statistical analysis of data. Houghton Mifflin, Boston, pp 432-439

19. Colle E, Siemiatycki J, West R, Belmonte MM, Crepeau MP, Poirier $R$, Wilkins J (1981) Incidence of juvenile onset diabetes in Montreal - demonstration of ethnic differences and socio-economic class differences. J Chronic Dis 34: 611-616

20. Dacou-Voutetakis C, Constantinidis M, Moschos A, Vlachou C, Matsaniotis N (1974) Diabetes mellitus following mumps. Am J Dis Child 127: $890-891$

21. Gamble DR, Taylor KW, Cumming H (1973) Coxsackie viruses and diabetes mellitus. Br Med J 4: 260-262

22. Christy M, Green A, Christau B, Kromann H, Nerup J (1979) Epidemiologic studies of insulin-dependent diabetes mellitus. Diabetes Care 2: 127-130

23. Platz P, Jakobsen BK, Morling N, Ryder LP, Svejgaard A, Thomsen $\mathrm{M}$, Christy M, Kromann $\mathrm{H}$, Benn J, Nerup J, Green A, Hauge M (1981) HLA-D and -DR antigens in genetic analysis of insulin dependent diabetes mellitus. Diabetologia 21:108-115

24. Farid NR, Sampson L, Noel P, Barnard JM, Davis AJ, Hillman DA (1979) HLA-D-related antigens in juvenile diabetes mellitus. Diabetes 28: 552-557

25. Wolf E, Spencer KM, Cudworth AG (1983) The genetic susceptibility to Type 1 (insulin-dependent) diabetes: analysis of the HLADR association. Diabetologia 24: 224-230

Received: 5 February 1986

and in revised form: 24 June 1986

Dr. D.J. D'Alessio

Department of Preventive Medicine

University of Wisconsin

504 N. Walnut Street

Madison, WI 53705

USA 